\title{
Effects of allopurinol on plasma uric acid levels in normouricaemic and hyperuricaemic green iguanas (Iguana iguana)
}

\author{
S. J. Hernandez-Divers, D. Martinez-Jimenez, S. Bush, K. S. Latimer, \\ P. Zwart, E. J. B. Veldhuis Kroeze
}

\begin{abstract}
A two-phase cross-over therapeutic study was performed with 19 green iguanas (Iguana iguana) maintained within a preferred optimum temperature range of 26 to $37^{\circ} \mathrm{C}$. During phase 1, they were fed a normal vegetarian diet and medicated orally with either allopurinol or a placebo control once a day for seven days. Uric acid concentrations, total protein, packed-cell volumes (PCV) and bodyweights were recorded from each lizard before and after treatment to determine the effects of allopurinol. In phase 2 , after a 10-day washout period, the iguanas were fed a high protein diet to induce hyperuricaemia. Normoand hyperuricaemic iguanas that received 24.2 (3.2) $\mathrm{mg} / \mathrm{kg}$ allopurinol had significantly lower mean (sd) uric

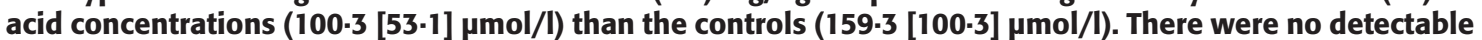
interactions between the doses of allopurinol or placebo, and the iguanas' diet, weight, PCV or total protein. The allopurinol was well tolerated, and there was no significant clinical, gross or histological evidence of hepatic or renal toxicity in the iguanas that received the drug. However, in the kidneys of the hyperuricaemic iguanas that did not receive allopurinol there were proliferative changes in the glomeruli and degeneration of tubular epithelia. Allopurinol given orally at $25 \mathrm{mg} / \mathrm{kg}$ daily is able to reduce plasma uric acid levels by 41 to $\mathbf{4 5}$ per cent, and is therefore recommended for the treatment of hyperuricaemia in the green iguana.
\end{abstract}

REPTILES are popular zoo exhibits and companion animals. They have been reported to suffer from kidney disease and gout, and the green iguana (Iguana iguana) has received particular attention in terms of both diagnosis and treatment (Keymer 1978a, b, Maxwell and Jacobson 2004, HernandezDivers and others 2005, Hernandez-Divers and Innis 2006, Mader 2006, Selleri and Hernandez-Divers 2006). Reptiles differ significantly from mammals in their renal anatomy and physiology (Dantzler 1976, Fitzsimons and Kaufman 1977, Guo and others 1996, Braun 1998, Benson and Forrest 1999, Hernandez-Divers and others 2005), in that they have paired metanephric kidneys, each containing a few thousand nephrons, compared with the million or so in most mammals. The reptilian nephron does not possess a loop of Henle, and the convoluted tubule (not the glomerulus) is supplied by a renal portal circulation. The distal tubule of mature male lizards undergoes hyperplasia during breeding periods, which causes gross and histological changes. The main nitrogenous product of most reptiles is uric acid; however, their renal function is otherwise not dissimilar from that of mammals and birds, with the osmoregulation of electrolytes and water balance being primary functions. Reptiles cannot concentrate urine above the concentration of plasma, although in several species there is significant post-renal modification of the urine across the bladder or cloacal membranes (Dantzler and Schmidt-Nielson 1966, Dantzler 1976).

The overproduction of, or failure to excrete, uric acid results in hyperuricaemia, which can lead to systemic or localised precipitation of urates in tissues (Agudelo and Wise 1991, Choy 2005, Kang and Nakagawa 2005). This condition is termed gout and is known to be painful in human beings. In captive reptiles, hyperuricaemia and gout have been associated with excess dietary protein and severe nephropathy (Keymer 1978a, b Montali and others 1979, Figureres 1997, Campbell 2006, Hernandez-Divers and Innis 2006, Mader 2006, Selleri and Hernandez-Divers 2006). Continued efforts in human medicine to improve the treatment of renal disease, hyperuricaemia and gout led to the development of allopurinol (4-hydroxypurinol), an isomer of hypoxanthine. Allopurinol is metabolised to oxypurinol by xanthine oxidase, and acts as a competitive antagonist of the enzyme that catalyses the conversion of hypoxanthine and xanthine to uric acid. It has been shown to be effective for decreasing blood uric acid levels in human beings, chimpanzees, chickens, turkeys and dogs (Weir and Fisher 1970, Czarnecki and others 1987, Smith and Wright 1987, Komoriya and others 1993, Bartges and others 1995, 1997b,) and has also been recommended for the treatment of ischaemia and leishmaniosis in dogs (Puig and others 1989, Emerit and Fabiani 1990, Liste and Gascon 1995, Kamau and others 2000, Colakoglu and others 2006, Pacher and others 2006).

The pharmacokinetics of allopurinol and its therapeutic effects have been studied in a variety of mammals and birds (Murrell and Rapeport 1986, Smith and Wright 1987, Bartges and others 1997a, b, Ling and others 1997, Poffers and others 2002). The bioavailability of allopurinol is unaffected by the presence of food but varies between species, being reportedly low in horses (14 per cent) and high in dogs and human beings (90 per cent) (Murrell and Rapeport 1986, Mills and others 1995, Bartges and others 1997b). The elimination halflife of allopurinol is short while that of its main metabolite, oxypurinol, is longer, and it accounts for most of the therapeutic effects. The drug is excreted mainly by the kidneys, but oxypurinol may accumulate in animals with renal dysfunction (Murrell and Rapeport 1986). In the red-tailed hawk (Buteo jamaicensis) oral allopurinol at 25, 50 and $100 \mathrm{mg} / \mathrm{kg}$ failed to prevent normal post-prandial hyperuricaemia, and at the higher doses caused toxic effects including vomiting and renal dysfunction (Poffers and others 2002). There have been several reports describing the beneficial effects of allopurinol in treating chelonians with hyperuricaemia and gout (Figureres 1997, Martinez-Silvestre 1997). However, there have been no controlled studies of the effects of allopurinol in any species of reptile.

To investigate the ability of allopurinol to decrease plasma uric acid levels in reptiles a therapeutic trial was conducted using the green iguana as a laboratory model. Green iguanas, maintained on either a normal vegetarian diet or a high protein (uricogenic) diet were medicated with either allopurinol or a placebo control for seven days. The effects of allopurinol were assessed by comparing the animals' bodyweights, plasma uric acid levels, plasma total protein and packed-cell volumes (PCV) before and after the treatment. In addition, possible microscopic changes were investigated by histology.
Veterinary Record (2008) 162, 112-115

S. J. Hernandez-Divers, BSc, CBiol, MIBiol, BVetMed, DZooMed, DACZM, MRCVS, D. Martinez-Jimenez, LV, MSc,

Department of Small Animal Medicine and Surgery,

S. Bush, MT(ASCP),

K. S. Latimer, DVM, $\mathrm{PhD}$, DACVP,

Department of Veterinary Pathology,

College of Veterinary Medicine, University of Georgia, Athens, GA 30602-7390, USA P. Zwart, DVM, PhD, DEAZVP,

E. J. B. Veldhuis Kroeze, DVM,

Department of Veterinary Pathology, Utrecht University, Yalelaan 1, 3584 CL Utrecht, The Netherlands 


\section{MATERIALS AND METHODS}

All the methods were evaluated and accepted by the University of Georgia's Institutional Animal Care and Use Committee. Nineteen green iguanas were maintained in facilities approved by the Association for Assessment and Accreditation of Laboratory Animal Care within the College of Veterinary Medicine. The lizards were two- to three-yearold subadult males weighing between 0.66 and $1.18 \mathrm{~kg}$ that had been maintained on an indigenous plant diet in outdoor enclosures in El Salvador during the previous 12 months. They were group housed in a dedicated animal room measuring $8 \mathrm{~m} \times 6 \mathrm{~m}$, with environmental control. Ten self-ballasted mercury vapour lamps (UVHeat; Westron Corporation) provided basking areas at $37^{\circ} \mathrm{C}$ and broad spectrum lighting during the day, and the diurnal air temperature in the room varied from 26 to $29^{\circ} \mathrm{C}$. The relative humidity varied from 60 to 90 per cent, and the photoperiod was set to 12 hours light and 12 hours dark. The iguanas were provided with fresh water ad libitum, and mixed green leafy vegetables, supplemented with calcium carbonate, every morning. A hosepipe was left trickling and the room was sprayed daily to provide additional humidity and drinking opportunities. The iguanas were acclimatised for seven days before the start of the study, and all of them were eating, drinking, urinating, defecating and behaving normally.

\section{Experimental design}

The cross-over study was conducted in two phases. During phase 1 , the 19 iguanas were fed a normal vegetarian diet and medicated orally with either allopurinol or a placebo control, once a day for seven days. Their bodyweights, plasma uric acid and total protein and PCV were recorded before and after the treatment to determine the effects of allopurinol. In phase 2 after a 10-day washout period, all the iguanas were fed a high protein diet to induce hyperuricaemia before they were treated in the same way.

\section{Therapeutic trial}

An oral suspension of $20 \mathrm{mg} / \mathrm{ml}$ allopurinol was compounded by using $100 \mathrm{mg}$ tablets (Allopurinol; Qualitest Pharmaceuticals) in syrupalta syrup (Huma Texarkana) according to published guidelines (Dressman and Poust 1983). The 19 iguanas were physically examined, accurately weighed, individually numbered, and randomly assigned to one of two treatment groups. The 10 iguanas in group A received $1 \mathrm{ml}$ of the allopurinol suspension $(20 \mathrm{mg})$ and the nine in group B received $1 \mathrm{ml}$ of syrupalta syrup by stomach tube every day for seven days. On day 1 the iguanas were examined, weighed and a blood sample $(0.5 \mathrm{ml})$ was collected from the caudal (ventral tail) vein with a $3 \mathrm{ml}$ syringe and $23 \mathrm{G} 2.54 \mathrm{~cm}$ needle into a lithium heparin plasma separator tube (Microtainer; Becton Dickinson Vacutainer Systems), which was kept on ice and processed within an hour of collection. Each iguana was restrained in a vertical position with its mouth held open by a rubber gag. A $4.7 \mathrm{~mm}$ (14 Fr) feeding catheter (Tyco Healthcare) with dosing syringe attached was advanced into the stomach and the $1 \mathrm{ml}$ dose was administered followed by $5 \mathrm{ml}$ of sterile saline (Braun Medical).

Two haematocrit tubes were filled with blood from the heparin blood tube, and centrifuged at $5000 \mathrm{~g}$ for five minutes; the PCV was read from both tubes with a haematocrit reader (Damon-IEC Division) and the mean value was recorded. The tubes were then broken above the buffy coat, and the plasma total protein concentration was measured with a hand-held refractometer (Reichert). The heparin separator tubes were centrifuged at $13,460 \mathrm{~g}$ for five minutes and the plasma was decanted and stored at $-70^{\circ} \mathrm{C}$ in microcentrifuge tubes (Eppendorf North America) until processed.
On day 8 , the iguanas were again examined, weighed and blood samples were collected in the same way.

All the plasma uric acid determinations were run as a single batch within two weeks of collection using an enzymatic colorimetric assay (UA Plus, BMC Liq Uric Acid kit \# 1661868; Roche Diagnostics) run on a BMC 912 chemistry analyser (Hitachi Nissei Sangyo America).

In phase 2, the iguanas were all maintained under the same management system, but each animal was supplemented with $10 \mathrm{ml}$ Hills a/d (Hills Pet Nutrition) starting three days before the start of the drug trial. The nine iguanas remaining in group A now received $1 \mathrm{ml}$ of syrupalta syrup and the nine in group B received $1 \mathrm{ml}$ of allopurinol suspension by stomach tube every day for seven days. The same method was used except that the stomach tubes were flushed with 10 $\mathrm{ml}$ Hills a/d rather than sterile saline after dosing. On day 8 the animals were examined, weighed and blood samples were taken as before.

\section{Postmortem examinations}

The 19 iguanas were euthanased with intravenous pentobarbitone (Beuthanasia; Schering-Plough Animal Health) one week after the study was completed. They were examined thoroughly and, together with any abnormal tissues, samples of liver and kidney were removed from each iguana, placed into 10 per cent neutral buffered formalin, and examined histologically. Representative sections were processed, embedded in paraffin, sectioned at $5 \mu \mathrm{m}$, and stained with haematoxylin and eosin, periodic acid-Schiff, reticulin and periodic acid methanamine silver, and examined by light microscopy.

\section{Statistical analysis}

The data were analysed by using SAS v 9.1 (SAS Institute). A Student's $t$ test $(\alpha=0 \cdot 05)$ was used to determine whether the diets affected the iguanas' uric acid, total protein, $\mathrm{PCV}$ or weight before they were treated, and a two-factor analysis of variance was used to determine whether the allopurinol or the diets affected the variables. An interaction term between the diets and the drug was also included, such that if $\mathrm{P}<0 \cdot 10$, indicating a potential interaction between them, then a Student's $t$ test for effect of the drug was applied to each diet separately.

\section{RESULTS}

All the iguanas were clinically healthy as determined by physical examinations, their normal feeding and behaviour, and ultimately postmortem examinations. The mean (sd) and 95 per cent confidence intervals of their weight, uric acid, total protein, PCV and dose of allopurinol were determined (Table $1)$. During the 10-day washout period, one male iguana in group A sustained tail damage during an aggressive encounter with a second male; it was subsequently removed from the study and did not participate in phase 2 .

No macroscopic abnormalities were observed postmortem but five random liver and kidney samples from group A and five from group B were evaluated histologically. The livers were normal. In the kidneys mild to marked sexual segment differentiation of the distal tubule was observed in three animals. The apical parts of the epithelial cells contained the characteristic eosinophilic globules present in sexually active male squamates. On slides where epididymal tubules were present spermatozoa were frequently observed. There were mild, adverse renal changes in only one of the lizards in group $\mathrm{A}$, including protein deposition in the glomerular capillaries, mild thickening of the capillary basement membranes, and proximal tubular irregularity and broadening of the brush borders.

The five lizards in group B were more severely affected, with protein deposits in the glomerular capillaries and 
thickening or splitting of the capillary basal membranes in three of them, proliferation of visceral epithelial cells of the Bowman's capsule in four, and proliferation of the parietal epithelium of the Bowman's capsule in two. In one animal, the urinary space of a few glomeruli contained a proteinaceous deposit. In three of the lizards the brush borders of the proximal tubules were irregular and broadened, there was cloudy swelling or vacuolation of the cellular protoplasm, pyknosis of the nuclei, and proteinaceous material within the lumen. In three of them there was necrosis of the epithelial cells, and degenerative changes in the distal tubules and collecting ducts ranging from vacuolation to necrosis. In one iguana the lumen of both the proximal and distal segments contained necrotic cells and the proteinaceous remnants of urate globules suggesting urinary stasis.

\section{DISCUSSION}

The dose of allopurinol that has been most commonly reported for reptiles is $20 \mathrm{mg} / \mathrm{kg}$ daily by mouth (MartinezSilvestre 1997, Divers 1998, Diethelm 2005), but in one case report an allometrically scaled dose of $3.31 \mathrm{mg} / \mathrm{kg}$ was used (Figureres 1997). Given the lack of pharmacokinetic data in reptiles, the iguanas were all given approximately $20 \mathrm{mg} / \mathrm{kg}$. The similarity in their bodyweights $(0.81[0.9] \mathrm{kg})$ resulted in a mean dose rate of $24 \cdot 2(3 \cdot 2) \mathrm{mg} / \mathrm{kg}$.

In an attempt to induce hyperuricaemia, the iguanas were fed a high protein supplement; their protein intakes from the vegetarian and high protein diets were estimated to be 1.0 $\mathrm{g} / \mathrm{kg} /$ day and $2.5 \mathrm{~g} / \mathrm{kg} /$ day, respectively. When fed the high protein diet their mean uric acid concentration was $218 \cdot 3$ $(106 \cdot 2) \mu \mathrm{mol} / \mathrm{l}$, significantly higher $(\mathrm{P}=0 \cdot 0028)$ than when they were fed the vegetarian diet $(129 \cdot 8[70 \cdot 8] \mu \mathrm{mol} / \mathrm{l})$. On the high protein diet their total protein concentration was 83 (9) g/l, compared with 74 (6) $\mathrm{g} / \mathrm{l}$ on the vegetarian diet $(\mathrm{P}=0.029)$. The high protein diet had no significant effect on their weight or PCV. Feeding a high protein diet, like Hills a/d, reliably induced hyperuricaemia and hyperproteinaemia in these iguanas, compared with those fed the lower protein vegetarian diet (Divers and others 1996, Harr and others 2001).

When the normo- and hyperuricaemic iguanas were treated with $24 \cdot 2(3 \cdot 2) \mathrm{mg} / \mathrm{kg}$ allopurinol daily for seven days they had significantly lower uric acid values $(100 \cdot 3$ [53.1] $\mu \mathrm{mol} / \mathrm{l})$ than the placebo-treated controls $(159.3$ $[100 \cdot 3] \mu \mathrm{mol} / \mathrm{l})(\mathrm{P}=0 \cdot 020)$ and previously published reference ranges (Divers and others 1996, Harr and others 2001), a reduction of 41 to 45 per cent. There were no detectable interactions between the doses of allopurinol or placebo and the iguanas' diet, weight, PCV or total protein concentrations. During phase 1 , both the pre- and post-treatment weights were significantly greater for group A (day $1,0 \cdot 88[0 \cdot 15] \mathrm{kg}$; day $8,0 \cdot 88[0 \cdot 14] \mathrm{kg}$ ) than group B (day $1,0 \cdot 76[0 \cdot 06] \mathrm{kg}$; day $8,0.76[0.06] \mathrm{kg})$; however, there were no significant interactions between their weight and uric acid, total protein, PCV, or treatment. This result was associated with the random selection of larger iguanas for group A.

Temperature has been shown to have inconsistent effects on drug pharmacokinetics in reptiles. For example, the pharmacokinetics of amikacin are affected by temperature in gopher snakes (Pituophis melanoleucus catenifer) (Mader and others 1985), but not in royal pythons (Python regius) (Johnson and others 1997). In the gopher tortoise (Gopherus polyphemus), the clearance of amikacin is affected by temperature but its half-life is not (Caligiuri and others 1990). The iguanas in this study were provided with a species-specific preferred optimum temperature range of 26 to $37^{\circ} \mathrm{C}$, rather than a fixed temperature. It is possible that the variable environmental temperature may have affected the pharmacokinetics of allopurinol and its effects, but lizards' metabolic

\begin{tabular}{|c|c|c|c|c|c|}
\hline \multicolumn{6}{|c|}{ 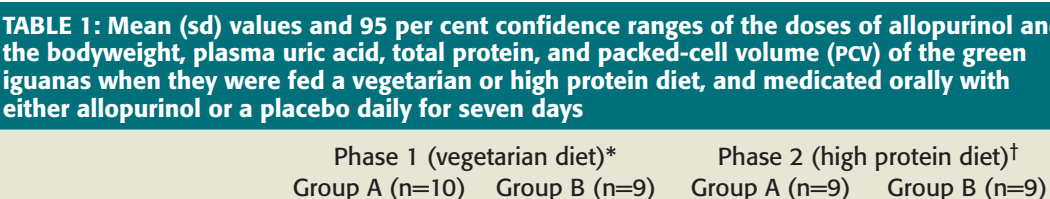 } \\
\hline \multicolumn{2}{|l|}{ Measurement } & $\begin{array}{l}\text { Group } A(n=10) \\
\text { (allopurinol) }\end{array}$ & $\begin{array}{l}\text { Group B }(n=9) \\
\quad \text { (placebo) }\end{array}$ & $\begin{array}{l}\text { Group } A(n=9) \\
\text { (placebo) }\end{array}$ & $\begin{array}{c}\text { Group B }(n=9) \\
\text { (allopurinol) }\end{array}$ \\
\hline \multicolumn{2}{|c|}{ Allopurinol dose $(\mathrm{mg} / \mathrm{kg})$} & $\begin{array}{l}22 \cdot 7(3 \cdot 8) \\
20 \cdot 3-25 \cdot 1\end{array}$ & NA & NA & $\begin{array}{l}25 \cdot 3(2 \cdot 6) \\
23 \cdot 6-27 \cdot 0\end{array}$ \\
\hline \multirow[t]{2}{*}{ Weight (kg) } & Day 1 & $\begin{array}{c}0.88(0.15) \\
0.79-0.97\end{array}$ & $\begin{array}{c}0.76(0.06) \\
0.73-0.80\end{array}$ & $\begin{array}{c}0.80(0.08) \\
0.75-0.86\end{array}$ & $\begin{array}{l}0.8(0.08) \\
0.74-0.85\end{array}$ \\
\hline & Day 8 & $\begin{array}{c}0.88(0.14) \\
0.79-0.97\end{array}$ & $\begin{array}{c}0.76(0.07) \\
0.72-0.80\end{array}$ & $\begin{array}{c}0.81(0.08) \\
0.76-0.86\end{array}$ & $\begin{array}{c}0.81(0.09) \\
0.75-0.87\end{array}$ \\
\hline \multirow[t]{2}{*}{ Uric acid $(\mu \mathrm{mol} / \mathrm{l})$} & Day 1 & $\begin{array}{c}130 \cdot 4(82 \cdot 4) \\
51 \cdot 1-79 \cdot 3\end{array}$ & $\begin{array}{c}123 \cdot 2(65 \cdot 4) \\
82 \cdot 7-163 \cdot 8\end{array}$ & $\begin{array}{c}207 \cdot 8(116 \cdot 9) \\
131 \cdot 5-284 \cdot 2\end{array}$ & $\begin{array}{l}226 \cdot 2(95 \cdot 9) \\
163 \cdot 5-288 \cdot 8\end{array}$ \\
\hline & Day 8 & $\begin{array}{c}77 \cdot 3(33 \cdot 7) \\
20 \cdot 9-56 \cdot 4\end{array}$ & $\begin{array}{l}99 \cdot 6(46 \cdot 9) \\
70 \cdot 6-128 \cdot 7\end{array}$ & $\begin{array}{c}213 \cdot 1(109 \cdot 1) \\
141 \cdot 8-284 \cdot 4\end{array}$ & $\begin{array}{c}123.9(66.8) \\
80.2-167.6\end{array}$ \\
\hline \multirow[t]{2}{*}{ Total protein $(\mathrm{g} / \mathrm{l})$} & Day 1 & $\begin{array}{l}76(6) \\
72-80\end{array}$ & $\begin{array}{l}76(7) \\
71-80\end{array}$ & $\begin{array}{c}78(10) \\
71-84\end{array}$ & $\begin{array}{l}84(8) \\
79-90\end{array}$ \\
\hline & Day 8 & $\begin{array}{l}75(6) \\
71-79\end{array}$ & $\begin{array}{l}73(6) \\
70-77\end{array}$ & $\begin{array}{l}83(8) \\
78-88\end{array}$ & $\begin{array}{c}83(11) \\
76-90\end{array}$ \\
\hline \multirow[t]{2}{*}{ PCV $(I / I)$} & Day 1 & $\begin{array}{c}0.36(0.03) \\
0.34-0.38\end{array}$ & $\begin{array}{c}0.37(0.04) \\
0.35-0.40\end{array}$ & $\begin{array}{c}0.38(0.05) \\
0.34-0.41\end{array}$ & $\begin{array}{c}0.39(0.06) \\
0.35-0.43\end{array}$ \\
\hline & Day 8 & $\begin{array}{c}0.35(0.03) \\
0.33-0.36\end{array}$ & $\begin{array}{c}0.36(0.04) \\
0.34-0.38\end{array}$ & $\begin{array}{c}0.33(0.03) \\
0.31-0.35\end{array}$ & $\begin{array}{c}0.31(0.05) \\
0.28-0.35\end{array}$ \\
\hline
\end{tabular}

processes tend to plateau rather than change proportionately with temperature when they are able to select a preferred body temperature from within their optimum range (Templeton 1964, Shoemaker and others 1966).

Allopurinol appeared to be well tolerated and did not cause any significant microscopic changes in the kidneys of the treated iguanas. In contrast there were several pathological changes in the placebo group. The aetiology of these changes is unclear; however, they may have been caused by high uric acid concentrations (or some other biochemical change) that was prevented by the treatment with allopurinol.

The oral dose of $24.2(3.2) \mathrm{mg} / \mathrm{kg}$ of allopurinol daily for seven days appeared to be well tolerated and without adverse clinical or histological effects on these green iguanas. This dose can therefore be recommended for the treatment of hyperuricaemia in iguanas.

\section{References}

AGUDELO, C. A. \& WISE, C. M. (1991) Gout and hyperuricemia. Current Opinions in Rheumatology 3, 684-691

BARTGES, J. W., OSBORNE, C. A., FELICE, L. J., KOEHLER, L. A., ULRICH, L. K., BIRD, K. A. \& CHEN, M. (1997a) Influence of two diets on pharmacokinetic parameters of allopurinol and oxypurinol in healthy beagles. American Journal of Veterinary Research 58, 511-515

BARTGES, J. W., OSBORNE, C. A., FELICE, L. J., KOEHLER, L. A., ULRICH, L. K., BIRD, K. A., CHEN, M. \& SAWCHUK, R. J. (1997b) Bioavailability and pharmacokinetics of intravenously and orally administered allopurinol in healthy beagles. American Journal of Veterinary Research 58, 504-510

BARTGES, J. W., OSBORNE, C. A., FELICE, L. J., UNGER, L. K. \& CHEN, M. (1995) Influence of allopurinol and two diets on 24-hour urinary excretions of uric acid, xanthine, and ammonia by healthy dogs. American Journal of Veterinary Research 56, 595-599

BENSON, K. G. \& FORREST, L. (1999) Characterization of the renal portal system of the common green iguana (Iguana iguana) by digital subtraction imaging. Journal of Zoo and Wildlife Medicine 30, 235-241

BRAUN, L. J. (1998) Comparative renal function in reptiles, birds and mammals. Seminars in Avian Exotic Pet Medicine 7, 62-71

CALIGIURI, R., KOLLIAS, G. V., JACOBSON, E. R., MCNAB, B., CLARK, C. H. \& WILSON, R. C. (1990) The effects of ambient temperature on amikacin pharmacokinetics in gopher tortoises. Journal of Veterinary Pharmacology and Therapeutics 13, 287-291

CAMPBELL, T. W. (2006) Clinical pathology. In Reptile Medicine and Surgery. 2nd edn. Ed D. R. Mader. Philadelphia, W. B. Saunders. pp 453-470 
CHOY, G. (2005) An update on the treatment options for gout and calcium pyrophosphate deposition. Expert Opinions in Pharmacotherapy 6, 24432453

COLAKOGLU, M., FIDAN YAYLALI, G., YALCIN COLAKOGLU, N. \& YILMAZ, M. (2006) Successful treatment of visceral leishmaniasis with fluconazole and allopurinol in a patient with renal failure. Scandinavian Journal of Infectious Disease 38, 208-210

CZARNECKI, C. M., OLIVERO, D. K. \& MCVEY, A. S. (1987) Plasma uric acid levels in ethanol-fed turkey poults treated with allopurinol. Comparative Biochemistry and Physiology C 86, 63-65

DANTZLER, W. H. (1976) Renal function (with special emphasis on nitrogen excretion). In Biology of the Reptilia, Physiology A. Eds C. Gans, W. R. Dawson. New York, Academic Press. pp 447-503

DANTZLER, W. H. \& SCHMIDT-NIELSON, B. (1966) Excretion in freshwater (Pseudemys scripts) and the desert tortoise (Gopherus agassizii). American Journal of Physiology 210, 198-210

DIETHELM, G. (2005) Reptiles. In Exotic Animal Formulary. 3rd edn. Ed J. W. Carpenter. St Louis, Elsevier Health Sciences. pp 55-131

DIVERS, S. J. (1998) Prescribing for reptiles. In The Veterinary Formulary. Ed Y. Bishop. London, Pharmaceutical Press. pp 90-99

DIVERS, S. J., REDMAYNE, G. \& AVES, E. K. (1996) Haematological and biochemical values of 10 green iguanas (Iguana iguana). Veterinary Record 138, 203-205

DRESSMAN, J. B. \& POUST, R. I. (1983) Stability of allopurinol and of five antineoplastics in suspension. American Journal of Hospital Pharmacology 40, 616-618

EMERIT, I. \& FABIANI, J. N. (1990) Allopurinol in ischemia-reperfusion injury of heart. Advances in Experimental Medicine and Biology 264, 367-372

FIGURERES, J. M. (1997) Treatment of articular gout in a Mediterranean pond turtle, Mauremys leprosa. Bulletin of the Association of Reptile and Amphibian Vets 7, 5-7

FITZSIMONS, J. T. \& KAUFMAN, S. (1977) Cellular and extracellular dehydration, and angiotensin as stimuli to drinking in the common iguana (Iguana iguana). Journal of Physiology 265, 443-463

GUO, M., DITRICH, H. \& SPLECHTNA, H. (1996) Renal vasculature and uriniferous tubules in the common iguana. Journal of Morphology 229, 97-104

HARR, K. E., ALLEMAN, A. R., DENNIS, P. M., MAXWELL, L. K., LOCK, B. A., BENNETT, R. A. \& JACOBSON, E. R. (2001) Morphologic and cytochemical characteristics of blood cells and hematologic and plasma biochemical reference ranges in green iguanas. Journal of the American Veterinary Medical Association 218, 915-921

HERNANDEZ-DIVERS, S. J. \& INNIS, C. (2006) Renal disease in reptiles: diagnosis and clinical management. In Reptile Medicine and Surgery. 2nd edn. Ed D. R. Mader. Philadelphia, W. B. Saunders. pp 878-892

HERNANDEZ-DIVERS, S. J., STAHL, S., STEDMAN, N. L., HERNANDEZDIVERS, S. M., SCHUMACHER, J., HANLEY, C. S., WILSON, G. H., VIDYASHANKAR, A. N., ZHAO, Y. \& RUMBEIHA, W. K. (2005) Renal evaluation in the green iguana (Iguana iguana): Assessment of plasma biochemistry, glomerular filtration rate, and endoscopic biopsy. Journal of Zoo and Wildlife Medicine 36, 155-168

JOHNSON, J. H., JENSEN, J. M., BRUMBAUGH, G. W. \& BOOTHE, D. M. (1997) Amikacin pharmacokinetics and the effects of ambient temperature on the dosage regimen in ball pythons (Python regius). Journal of Zoo and Wildlife Medicine 28, 80-88

KAMAU, S. W., HURTADO, M., MULLER-DOBLIES, U. U., GRIMM, F. \& NUNEZ, R. (2000) Flow cytometric assessment of allopurinol susceptibility in Leishmania infantum promastigote. Cytometry 40, 353-360
KANG, D. H. \& NAKAGAWA, T. (2005) Uric acid and chronic renal disease: possible implication of hyperuricemia on progression of renal disease. Seminars in Nephrology 25, 43-49

KEYMER, I. F. (1978a) Diseases of chelonians: (1) necropsy survey of tortoises. Veterinary Record 103, 548-552

KEYMER, I. F. (1978b) Diseases of chelonians: (2) necropsy survey of terrapins and turtles. Veterinary Record 103, 577-582

KOMORIYA, K., OSADA, Y., HASEGAWA, M., HORIUCHI, H., KONDO, S. COUCH, R. C. \& GRIFFIN, T. B. (1993) Hypouricemic effect of allopurinol and the novel xanthine oxidase inhibitor TEI-6720 in chimpanzees. European Journal of Pharmacology 250, 455-460

LING, G. V., CASE, L. C., NELSON, H., HARROLD, D. R., JOHNSON, D. L. \& VULLIET, P. R. (1997) Pharmacokinetics of allopurinol in Dalmatian dogs. Journal of Veterinary Pharmacology and Therapeutics 20, 134-138

LISTE, F. \& GASCON, M. (1995) Allopurinol in the treatment of canine visceral leishmaniasis. Veterinary Record 137, 23-24

MADER, D. R. (2006) Gout. In Reptile Medicine and Surgery. 2nd edn. Ed D. R. Mader. Philadelphia, W. B. Saunders. pp 793-800

MADER, D. R., CONZELMAN, G. J. \& BAGGOT, J. D. (1985) Effects of ambient temperature on the half-life and dosage regimen of amikacin in the gopher snake. Journal of the American Veterinary Medical Association 187, 1134-1136

MARTINEZ-SILVESTRE, A. (1997) Treatment with allopurinol and probenecid for visceral gout in a Greek tortoise, Testudo graeca. Bulletin of the Association of Reptile and Amphibian Vets 7, 4-5

MAXWELL, L. K. \& JACOBSON, E. R. (2004) Allometric scaling of kidney function in green iguanas. Comparative Biochemistry and Physiology Part A Molecular and Integrative Physiology 138, 383-390

MILLS, P. C., DUNNETT, M. \& SMITH, N. C. (1995) The pharmacokinetics of oral and intravenous allopurinol and intravenous oxypurinol in the horse. Journal of Veterinary Pharmacology and Therapeutics 18, 451-456

MONTALI, R. J., BUSH, M. \& SMELLER, J. M. (1979) The pathology of nephrotoxicity of gentamicin in snakes. A model for reptilian gout. Veterinary Pathology 16, 108-115

MURRELL, G. A. \& RAPEPORT, W. G. (1986) Clinical pharmacokinetics of allopurinol. Clinical Pharmacokinetics 11, 343-353

PACHER, P., NIVOROZHKIN, A. \& SZABO, C. (2006) Therapeutic effects of xanthine oxidase inhibitors: renaissance half a century after the discovery of allopurinol. Pharmacological Reviews 58, 87-114

POFFERS, J., LUMEIJ, J. T., TIMMERMANS-SPRANG, E. P. \& REDIG, P. T. (2002) Further studies on the use of allopurinol to reduce plasma uric acid concentrations in the red-tailed hawk (Buteo jamaicensis) hyperuricaemic model. Avian Pathology 31, 567-572

PUIG, J. G., MATEOS, F. A. \& DIAZ, V. D. (1989) Inhibition of xanthine oxidase by allopurinol: a therapeutic option for ischaemia induced pathological processes? Annals of Rheumatic Diseases 48, 883-888

SELLERI, P. \& HERNANDEZ-DIVERS, S. J. (2006) Renal diseases of reptiles. Veterinary Clinics of North America Exotic Animal Practice 9, 161-174

SHOEMAKER, V. H., LICHT, P. \& DAWSON, W. R. (1966) Effects of temperature on kidney function in the lizard Tiliqua rugosa. Physiological Zoology 39, 244-252

SMITH, G. W. \& WRIGHT, V. (1987) Allopurinol. British Journal of Clinical Practice 41, 710-711

TEMPLETON, J. R. (1964) Cardiovascular response to temperature in the lizard Sauromalus obesus. Physiological Zoology 37, 300-306

WEIR, E. \& FISHER, J. R. (1970) The effect of allopurinol on the excretion of oxypurines by the chick. Biochimica Biophysica Acta 222, 556-557 